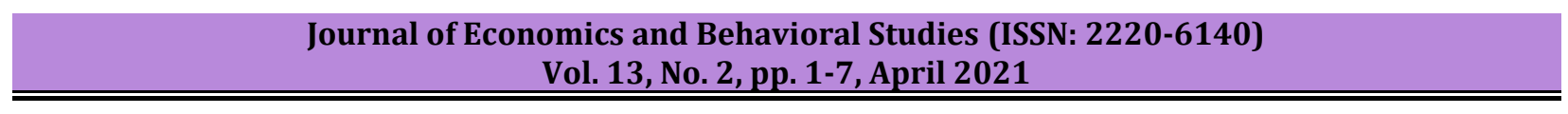

\title{
Effect of Tax Avoidance and Company Complexity on Firm Value: The Role of Transparency as a Moderating Variable
}

\author{
Thalia Millene Suryani, Noegrahini Lastiningsih, Ekawati Jati Wibawaningsih \\ Universitas Pembangunan Nasional Veteran Jakarta, Indonesia \\ noegrahini@gmail.com
}

\begin{abstract}
This study aims to analyze the effect of tax avoidance and company complexity on firm value with information transparency as a moderating variable so that internal and external parties can evaluate management performance to increase firm value positively. In this study, panel data regression and Moderated Regression Analyst (MRA) were carried out on 78 public manufacturing companies on the IDX during the 2017-2019 period. Tax avoidance is measured by the BTD proxy, the level of complexity is measured by the number of business segments, firm value is measured by Tobin's q proxy, and information transparency is measured by the transparency index released by BAPEPAM. The results show that tax avoidance has a significant negative effect on firm value and firm complexity does not have a significant effect on firm value, while information transparency moderates the relationship between tax avoidance and firm value but is unable to moderate the effect of firm complexity on firm value.
\end{abstract}

Keywords: Tax Avoidance, Company Complexity, Diversification, Firm Value, Transparency.

\section{Introduction}

Before the 1980s, oil and natural gas played an important role in state financial revenues, however, the times and the rate of world inflation which inevitably resulted in the sluggish price of oil and natural gas, led to a decline in state financial revenues. Realizing this, the government is looking for a substitute for state revenue and the choice falls on taxes. Tax is one of the three sources of state income that has the largest portion when compared to other state revenues, namely non-tax state revenue and domestic and foreign grant. Reporting from the State Revenue and Expenditure Budget report for the 2019 budget issued, by the Ministry of Finance, tax revenue is IDR 2,164.7 B or contributes more than $80 \%$ of state revenue and this figure continues to increase every year, especially with the increase in population.

This tax revenue is used to finance national development and to make the community prosperous. However, the government's efforts in demanding tax obligations from the public are still not optimal as seen by not achieving the state revenue target in the 2017-2019 period. The unrealized revenue target has an impact on the low tax ratio. This ratio is inversely proportional to the tax ratio in Indonesia in 2016 which was $10.8 \%$, in 2017 it was $10.7 \%$, in 2018 it was $11.5 \%$ and in 2019 it was $11.9 \%$ (presented in Table 1). The tax ratio describes the level of tax compliance and tax compliance culture, including the law enforcement system. In other words, the tax ratio must match economic growth. This fact shows that there is a research gap, that is, an increasing tax ratio does not reflect an increase in economic growth. This phenomenon shows the high tax avoidance in Indonesia.

Table 1: Tax Ratio in Indonesia

\begin{tabular}{llll}
\hline & $\mathbf{2 0 1 7}$ & $\mathbf{2 0 1 8}$ & $\mathbf{2 0 1 9}$ \\
\hline Tax Ratio & 10.8 & 10.7 & 11.5 \\
\hline
\end{tabular}

The phenomenon of tax avoidance practices has recently been carried out by a coal mining company, namely PT Adaro Energy. Adaro was proven to have committed tax avoidance of US \$ 125 million or equivalent to Rp1.82 trillion during 2009-2017. Adaro uses its subsidiary as a tool to make a big profit from the coal trade and mining in Singapore, namely Coal trade Services International, by selling mining products to the subsidiary and the subsidiary will sell at a higher price. Singapore is Adaro's choice of place for the transfer pricing scheme due to the low-income tax rate of 10\% in Singapore, compared to the income tax rate of $28 \%$ in Indonesia. Adaro's scheme does not violate the rules, but it is not ethical to do so. This is due to the Adaro benefits from existing resources in Indonesia, but the tax revenue that Indonesia receives is not optimal. Companies that succeed in saving tax burdens will increase company profits (Nugraha \& Setiawan, 2019). 
However, in implementing the costs incurred are not small, there are implementation costs, costs of losing the company's reputation and potential fines that may occur (Chen et al., 2014; Santana \& Rezende, 2016). Apart from tax avoidance factors, another component that affects firm value is firm complexity.

A company that is successful in its activities will enlarge its business with the hope of earning a profit or increasing the company's reputation by expanding or expanding its business. This has an impact on increasing profits received from many business segments and subsidiaries so that it will attract investors to invest (Jia, 2010; Khan et al., 2020). Even so, the increasing number of subsidiaries or business segments will not only increase the profit of the parent company and dominate market share, but will also cause significant costs of establishment, acquisition costs and operational supervision costs that can become a burden to the company (Queen, \& Fasipe, 2015). Therefore, the company's decision to expand or not depends on how the company applies it, whether it can benefit or even harm the company.

Based on the phenomenon and differences in the results of previous studies regarding the effect of tax avoidance and company complexity on firm value, it is a reason to add company transparency as a moderating variable. Transparency can be calculated from the amount of information presented by management in an annual report. Low transparency indicates poor corporate governance and causes large differences in information resulting in weak relationships with investors, and vice versa (Khan et al., 2020; Noviari \& Suaryana, 2019). The purpose of this research is to analyze the effect of tax avoidance and company complexity on the value of the manufacturing sector companies listed on the Indonesia Stock Exchange and the effect of information transparency in moderating these two variables.

\section{Literature Review and Hypothesis Development}

Agency Theory: According to Bendickson (2016), agency theory is an understanding based on one party, namely the shareholder as the principal, who assigns certain tasks and decisions to other parties, namely the manager as an agent. The company system that separates agents and principals can cause problems, including the possibility of agents carrying out activities that are not in line with the wishes or interests of the principal. Sukandar and Rahardja (2014) describe the inequality of interests between agents and principals as agency problems. Agents tend to prioritize their interests to get maximum compensation or incentives. One of the opportunistic actions taken by agents is implementing tax avoidance practices such as manipulating income that can harm the principal and creditors. Contrary to the agent's behavior, the principal wants an increase in firm value so that it will have an impact on a large and consistent rate of return on the capital they provide (Priyadi, 2017). In addition, agents also tend to diversify their business without focusing on major investments to increase profits but do not see long-term impacts on the company (El-Mehdi, 2011; Choe et al., 2014).

Signal Theory: According to Godfrey et al. (2010), the signal theory explains the reasons for the behavior of managers as agents to provide signals about the company's prospects. This behavior aims to reduce the level of information asymmetry between the company's internal and external parties. Signals are relevant and material information about everything that the company has done to achieve the desires of its owners. In practice, management strives to disclose more information that can highlight the integrity and success of the company so that it will be considered both by investors and shareholders even though the information is not required (Astuti \& Pamudji, 2015). Stiglitz (2002) in Connelly (2014) explains that the occurrence of information asymmetry is when different parties understand different things. This is because some information is personal, so that information asymmetry arises between those who have the information and those who can make better decisions if they have the information. When the level of company diversification is greater, it will increase the complexity of the company which can increase the risk of information asymmetry. Therefore, the company is expected to consistently provide positive signals to investors and the public to increase trust and guarantee the security of investments that have been deposited in the company.

Firm Value: Company value is an understanding from the investor's side of the company's performance, and the value of its shares (Simetris \& Darmawan, 2019). So, the higher the share price will be directly proportional to the value of the company, meaning that maximizing company value also means maximizing the interests of shareholders, which is one of the company's missions. As the main barometer of a company's 
success, the company's value is required to always increase in the hope of building investor confidence not only in the company's current performance but also in the company's future projections (Nawaiseh, 2017). A good level of transparency is expected to minimize the opportunistic behavior of managers and detect risks. One way for companies to increase complexity is by developing a business or diversification (Wibowo, 2020). In addition, related to company liquidity, the company is considered capable of repaying loans provided by creditors, thereby facilitating the process of obtaining additional capital (Susanti \& Restiana, 2018).

Tax Avoidance: Tax avoidance is a situation when a company implements a certain taxation policy that allows taxation actions taken by the company to not be questioned from a legal point of view, but these actions are considered risky if proven to have violated applicable laws (Tandean \& Winnie, 2016). By law, the practice of tax avoidance is permissible because it is done by taking advantage of the tax loophole by reducing information about the tax burden that should be paid. Previous research conducted by Chen et al. (2014) and Santana \& Rezende (2016) proved that tax avoidance has a negative effect on firm value because it will cause various problems that can be costly. This result is inversely proportional to the study of Nugraha \& Setiawan (2019) which concluded that the existence of tax avoidance directly increases firm value.

H1. Tax Avoidance has a positive effect on company value.

Company Complexity: Company complexity is related to the complexity of company transactions (Rukmana et al., 2017). The complexity of the company is based on the number of operating units, diversification of product lines and markets, and the formation of departments and work departments that focus on the number of different units. One way for companies to increase complexity is by developing a business or diversification (Wibowo, 2020). With business expansion, if one company bears a loss, the other company will still get the profit it should, so that the overall profit obtained is more stable and the risk is smaller (Sudana, 2019). A previous study conducted by El-Mehdi (2011) and Cheo et al. (2014) proved that there was a positive impact on company value if the business was verified, namely companies could reduce their debt ratio and control the available market share and allow them to allocate resources between companies. Thus reducing internal financing. However, in the results of research by Chen et al. (2014), it is concluded that the high level of complexity of companies that have complex management makes it easy for them to carry out earnings management so that it can reduce firm value.

H2. Firm complexity has a positive effect on firm value.

Transparency: Information transparency, namely disclosure of company facts in disclosing material and relevant information. The disclosure as referred to in the Regulation of the Financial Services Authority of the Republic of Indonesia Number 37 / POJK.03 / 2019 includes important and relevant material information or facts regarding events, incidents or facts that may influence the decisions of the parties concerned regarding information or facts. Investors will study these financial reports to understand the strategic risks and company performance to determine the decisions to be taken. Chen et al. (2014) and Nugraha \& Setiawan (2019) concluded that information transparency can moderate the negative relationship between tax avoidance and firm value because the existence of information transparency can increase investor confidence so that they continue to invest even in a company doing tax avoidance practices. Furthermore, research by Jia (2010) concluded that the existence of information transparency cannot moderate the relationship between firm complexity and firm value, because logically the size of the company value is not always seen from the level of complexity of the company but rather the ability or management creativity in managing assets so that the business able to grow.

H3. Information transparency moderates the relationship between tax avoidance and firm value and the relationship between firm complexity and firm value.

\section{Research Method}

In this study, manufacturing companies listed on the Indonesia Stock Exchange in 2017-2019 were used as objects of study. Manufacturing companies are the industrial sector that processes raw materials into finished or semi-finished goods and is considered one of the backbones of the country's economy. Using a purposive sampling method, 78 companies were selected from a total of 192 manufacturing companies that obtained the desired sample criteria as follows: 


\section{Table 2: Research Sample Criteria}

\begin{tabular}{lll}
\hline No & Criteria & Total \\
\hline 1 & Manufacturing sector companies listed on the IDX during 2017-2019 & 192 \\
2 & Companies did not publish annual financial statements in Rupiah for 2017-2019 & $(30)$ \\
3 & $\begin{array}{l}\text { Companies did not publish annual financial reports that have been audited by independent } \\
\text { auditors in full and consecutively during 2017-2019 }\end{array}$ & $(47)$ \\
4 & Companies with positive profits during the 2017-2019 period & $(27)$ \\
5 & Companies that include information on at least one or more business segments & $(4)$ \\
The number of companies selected to be the sample & $\mathbf{7 8}$ \\
\hline
\end{tabular}

\section{Results}

Descriptive Statistics: Table 3 shows that the number of samples (N) used in this study was 234 samples, the smallest firm value was 0.329 the largest was 23.28 with an average of 2.08 and a standard deviation of 2.76. The tax avoidance calculated using the BTD ratio has a minimum value of -0.23 and a maximum value of 0.87 and an average of -0.011 with a standard deviation of 0.083 . Furthermore, the complexity of the company shows an average of 2.88 with a minimum value of 1 and a maximum of 7 and a standard deviation of 1.54 which is below the average, so it can be concluded that the data varies. The moderating variable, namely transparency of information, has an average of 0.71 with the smallest value of 0.48 and the largest of 0.94 , indicating that sample companies have submitted their financial report results in accordance with government regulations.

Table 3: Descriptive Statistics

\begin{tabular}{llllll}
\hline Variable & Total & Mean & Std. Dev & Min & Max \\
\hline FP & 234 & 2.080313 & 2.761118 & .3293315 & 23.28575 \\
TA & 234 & -.0115315 & .0837536 & -.2309555 & .8794016 \\
CC & 234 & 2.888889 & 1.540736 & 1 & 7 \\
T & 234 & .7170085 & .0943445 & .48 & .94 \\
\hline
\end{tabular}

Furthermore, before performing a regression test, it is necessary to test classical assumptions to meet the requirements and conditions of panel data regression. The first test is a normality test using the skewness kurtosis technique, with a threshold of \pm 3 for skewness and \pm 10 for kurtosis. However, the data in this study proved to be abnormal, so minorize must be done to eliminate the possibility of outliers in all variables to maintain the original data features. Furthermore, the multicollinearity test was carried out by looking at the VIF value, where the VIF value that is good or reflects the absence of multicollinearity symptoms is when the VIF value is $<10$ or tolerance $>0.1$. The results show that the data in this study are declared free of multicollinearity symptoms. The final step is the heteroscedasticity test with the Breusch Pagan Godfrey method where there is a significant requirement of $5 \%(0.05)$, but the test results are below the threshold so that robustness treatment must be carried out.

Panel Data Regression Analysis

Table 4: Panel Data Regression Analysis Test Results

\begin{tabular}{lllllll}
\hline FV-w & Coef. & $\begin{array}{l}\text { Robust } \\
\text { Std. Err. }\end{array}$ & t & P> I t I & [95\% Conf. & Interval] \\
\hline TA_w & -11.04627 & 3.106397 & -3.56 & 0.000 & -17.16676 & -4.925773 \\
CC & .0387897 & .0504075 & 0.77 & 0.442 & -.0605275 & .1381069 \\
_cons & 1.497177 & .01812036 & 8.26 & 0.000 & 1.140153 & 1.8542 \\
\hline
\end{tabular}

Based on Table 4 above, tax avoidance it is known that the $t$ value is -3.56 , where the probability level or $\mathrm{p}$ value is 0.000 . Based on the test results, the tax avoidance partially affects the firm value because the p-value 
$(0.000)$ is below the significance level $(0.05)$. The conclusion from the t-test results is that tax avoidance has a significant relationship in the opposite direction to changes in firm value. So, it can be concluded that the first hypothesis is rejected because tax avoidance has a negative effect on firm value. The test results are in line with the research of Chen et al. (2014) and Santana \& Rezende (2016). On the other hand, it is contrary to the results by Nugraha and Setiawan (2019) which state that there is a positive influence on the firm value if management decides to implement tax avoidance practices.

Furthermore, for the company complexity, it is known that the $t$ value is 0.77 , where the probability level or $\mathrm{p}$-value is 0.442 . Based on the test, it can be concluded that the company complexity partially does not affect firm value because the p-value (0.442) is above the significance level (0.05). Thus, it can be concluded that the first hypothesis is rejected because the size of the company complexity does not affect firm value. The test results are consistent with Khan et al. (2020) and Queen and Fasipe (2015) who state that there is no significant relationship between firm complexity and firm value. On the other hand, the results of the study contradict the results suggested by Jia (2010) that the complexity of companies in China can increase firm value.

Moderated Regression Analyst

Table 5: MRA Test Model 1

- regress NP_w TA_w TI TA_TI_w

\begin{tabular}{|c|c|c|c|c|c|c|}
\hline Source & sS & $d f$ & MS & Number of obs & $=$ & 234 \\
\hline Model & 83.7117189 & 3 & 27.9039063 & Prob > F & $=$ & 0.0000 \\
\hline Residual & 345.515367 & 230 & 1.50224073 & R-squared & $=$ & 0.1950 \\
\hline Total & 429.227086 & 233 & 1.84217633 & Root MSE & $=$ & $\begin{array}{l}0.1845 \\
1.2257\end{array}$ \\
\hline
\end{tabular}

\begin{tabular}{r|rrrrrr}
\hline NP_w & Coef. & Std. Err. & $t$ & $\mathrm{P}>|\mathrm{t}|$ & [95\% Conf. Interval] \\
\hline TA_w & 40.99838 & $\mathbf{2 4 . 2 2 0 2 8}$ & $\mathbf{1 . 6 9}$ & 0.092 & -6.723608 & $\mathbf{8 8 . 7 2 0 3 7}$ \\
TI & $\mathbf{4 . 3 2 2 3 1 1}$ & $\mathbf{. 9 2 2 8 4 5 9}$ & $\mathbf{4 . 6 8}$ & $\mathbf{0 . 0 0 0}$ & $\mathbf{2 . 5 0 3 9 9 8}$ & $\mathbf{6 . 1 4 0 6 2 4}$ \\
TA_TI_w & $-\mathbf{7 1 . 2 3 2 0 7}$ & $\mathbf{3 4 . 1 1 0 1 7}$ & -2.09 & 0.038 & -138.4404 & $-\mathbf{4 . 0 2 3 7 1 7}$ \\
_cons & $\mathbf{- 1 . 4 9 5 4 6 4}$ & $\mathbf{. 6 5 8 8 1 7 4}$ & -2.27 & 0.024 & -2.793552 & -.1973748 \\
\hline
\end{tabular}

Based on Table 5, tax avoidance which is the result of the multiplication interaction between the tax avoidance and information transparency, the $t$ value is -2.09 with a probability value of 0.038 . This probability value is below the level of significance, so it can be concluded that transparency is significant and moderates the relationship between tax avoidance and firm value. The negative value of the probability of tax avoidance shows that the existence of information transparency will weaken the relationship between tax avoidance and firm value. In the company complexity which is the result of the multiplication interaction between company complexity and information transparency, the probability is 0.112 . This value is far above the level of significance (0.05), so it is stated that transparency is not significant and is not a moderating the relationship between company complexity and firm value.

\section{Conclusion}

Based on the objectives of this study, it can be concluded that tax avoidance has a significant effect on firm value but in a negative direction. The majority of manufacturing companies in Indonesia view tax avoidance as having more of a downside than seeing it as an acceptable benefit in the future. In addition, there is no influence between the level of company complexity and firm value. This occurs because logically the size of the company value is not always seen from the level of company complexity, but rather the ability or creativity of management in managing assets so that the business is able to develop. On the other hand, it is 
concluded that information transparency able to moderate the relationship between tax avoidance and firm value in a negative direction and transparency is unable to moderate the relationship between company complexity and firm value. This study has several limitations, namely the minimum number of samples and there are unbalanced measurement results, where there are data with very high values and data with very low values, causing deviations and making testing difficult. Based on these limitations, it is recommended for further research to expand the object and year of observation so that the results obtained are more universal and replace or add proxy and index measurement variables with others and adjusted to the current situation.

\section{References}

Astuti, P. \& Pamudji, S. (2015). Analisis pengaruh opini going concern, likuiditas, solvabilitas, arus kas, umur perusahaan dan ukuran perusahaan terhadap kemungkinan financial distress. Diponegoro Journal of Accounting, 142-152.

Bendickson, J., Muldoon, J., Liguori, E. W. \& Davis, P. E. (2016). Agency Theory: Background and Epistemology. Journal of Management History, 22(4), 437-449.

Bergh, D. D., Connelly, B. L., Ketchen Jr, D. J. \& Shannon, L. M. (2014). Signalling Theory and Equilibrium in Strategic Management Research: An Assessment and a Research Agenda. Journal of Management Studies, 51(8), 1334-1360.

Chen, Z., Cheok, K. C. \& Rasiah, R. (2014). Corporate Tax Avoidance and Performance: Evidence from China's Listed Companies. Institutions and Economies, 8(3), 61-83.

Choe, C., Dey, T. \& Mishra, V. (2014). Corporate diversification, executive compensation and firm value: Evidence from Australia. Australian Journal of Management, 39(3), 395-414.

Desai, M. A. \& Dharmapala, D. (2009). Corporate Tax Avoidance and Firm Value. The review of Economics and Statistics, 91(3), 537-546.

Dyreng, S. D., Hanlon, M. \& Maydew, E. L. (2010). The Effect of Executives on Corporate Tax Avoidance. The Accounting Review, 85, 1163-1189.

El Mehdi, I. K. \& Seboui, S. (2011). Corporate diversification and earnings management. Review of Accounting and Finance, 10(2), 176-196.

Godfrey, J., Hodgson, A., Tarca, A., Hamilton, J. \& Holmes, S. (2010). Accounting Theory (7th Ed.). New York: McGraw Hill.

Jia, X. (2010). Complex Organizational Structure and Chinese Firm Value. Wharton Scholars Research Journal: University of Pennsylvania.

Khan, M. H., Bhatti, H. Y., Hassan, A. \& Fraz, A. (2020). The diversification-performance nexus: mediating role of information asymmetry. Journal of Management and Governance, 1-24.

Nawaiseh, M. (2017). The Impact of the Financial Performance on Firm Value: Evidence from Developing Countries. International Journal of Applied Business and Economic Research, 15(16), 241-253.

Nugraha, M. C. J. \& Setiawan, P. E. (2019). Pengaruh Penghindaran Pajak (Tax Avoidance) Pada Nilai Perusahaan Dengan Transparansi Sebagai Variabel Pemoderasi. E-Jurnal Akuntansi, 26(1), 398-425.

Noviari, N. \& Suaryana, I. G. N. A. (2019). Mampukah Corporate Governance Mengurangi Eksekutif Risk Taker Melakukan Penghindaran Pajak? Jurnal Ilmiah Akuntansi dan Bisnis, 14(2), 265-275.

Priyadi, M. P. (2017). Pengaruh Kinerja Keuangan terhadap Nilai Perusahaan dengan Good Corporate Governance sebagai Variabel Pemoderasi. Jurnal Ilmu dan Riset Akuntansi (JIRA), 6(7), 1-25.

Queen, P. E. \& Fasipe, O. (2015). Understanding the Impact of Business Complexity on Executive Management Characteristics and Firm Performance. Journal of Accounting \& Finance, 15(3), 2158-3625.

Rukmana, M., Konde, Y. T. \& Setiawaty, A. (2017). Pengaruh Risiko Litigasi, Corporate Governance, Karakteristik Perusahaan, dan Karakteristik Auditor terhadap Audit Fee pada Perusahaan yang Terdaftar di BEI. Simposium Nasional Akuntansi, 20.

Santana, S. \& Rezende, A. J. (2016). Corporate tax avoidance and firm value: evidence from Brazil. Universidade Federal de Santa Catarina, 13(30), 114-133.

Simetris, S. A. \& Darmawan, A. (2019). Pengaruh Diversifikasi, Leverage Dan Profitabilitas Terhadap Nilai Perusahaan (Studi pada Perusahaan Industri Barang Konsumsi yang Terdaftar Di Bursa Efek Indonesia Tahun 2013-2017). Jurnal Administrasi Bisnis, 74(1), 39-47.

Sudana, I. M., Imaniar, F. B., Sasikirono, N. \& Singh, S. K. (2019). Diversification and cash holdings: comparison between Indonesia and the Netherlands firms. International Journal of Monetary Economics and Finance, 12(2), 133-151. 


\section{Journal of Economics and Behavioral Studies (ISSN: 2220-6140)}

Vol. 13, No. 2, pp. 1-7, April 2021

Sukandar, P. P. \& Rahardja, R. (2014). Pengaruh Ukuran Dewan Direksi Dan Dewan Komisaris Serta Ukuran Perusahaan terhadap Kinerja Keuangan Perusahaan (Studi Empiris Pada Perusahaan Manufaktur Sektor Consumer Good yang Terdaftar di BEI Tahun 2010-2012). Diponegoro Journal of Accounting, 689-695.

Susanti, N. \& Restiana, N. G. (2018). What's the Best Factor to Determining Firm Value? Jurnal Keuangan dan Perbankan, 22(2), 301-309.

Stiglitz, J. E. (2002). Globalization and its discontents. Norton \& Company.

Tandean, V. A. \& Winnie, W. (2016). The Effect of Good Corporate Governance on Tax Avoidance: An Empirical Study on Manufacturing Companies Listed in IDX period 2010-2013. Asian Journal of Accounting Research, 1(1), 28-38.

Unit Khusus Museum Bank Indonesia. Sejarah Bank Indonesia: Moneter Periode. (1983-1997).

Wang, J. \& Zhang, Q. (2009). Information Transparency and Manager Compensation Effectiveness: Evidence from Chinese Securities Market. Nankai Business Review, 5, 94-100.

Wibowo, A. (2020). Corporate Strategy: Konsep dan Praktik. Yogyakarta: Penerbit Andi. 